\title{
AN ANALYSIS OF DEIXIS ON ANIES BASWEDAN'S SPEECH ABOUT CONDOLENCES FOR THE CITY OF CHRISTCHURCH, NEW ZEALAND
}

\author{
Dicky Abdul Jabbar ${ }^{1}$, Acep Haryudin² \\ ${ }^{1}$ IKIP Siliwangi \\ ${ }^{2}$ IKIP Siliwangi \\ ${ }^{1}$ dickyaj27@ student.ikipsiliwangi.ac.id, ${ }^{2}$ haryacep@gmail.com
}

\begin{abstract}
This study aims to identify types of deixis. research focus on speeches conducted by Anies Baswedan in condolences for acts of terrorism that occurred in the city of Christchurch, new zealand, which was uploaded on the Jakarta provincial government on youtube channel. The researchers used qualitative descriptive methods. It starts with searching and downloading videos on Youtube, recording speeches delivered in the video, and analyzing what types of deixis are used. in this study obtained a total of 25 data and all types of deixis used by Anies baswedan in his speech, namely person deixis, place deixis, time deixis, discourse deixis, and social deixis.
\end{abstract}

Keywords: Deixis, Anies Baswedan's Speech.

\section{INTRODUCTION}

Language is an important link between humans. with language, humans can provide and receive information with other humans. some examples of information such as ideas, experiences conveyed by communication, communication can take the form of oral or written. According to Wiguna et al., (2018) Humans are social beings who need each other in their social life. To communicate with other beings in their daily life or in their social life they need a language to interact and work together. Based on that statement above, communication can be said "good" if the listener can understand clearly what is meant by the speaker, so that every human being will be able to make good interactions with other humans.

Speech is an interest of public speaking or giving speeches to explicit their opinions, or provide an outline of a matter. According to Ardeatika \& Setiawan (2019) Language is used as a media of communication. With language, anyone can transfer what mean to others. Based on that statement above, a speaker must use good language and easy to understand so that what he wants to convey can be well received by the listener. Speeches are generally added by a person who offers speeches and statements approximately an vital thing/event worth mentioning. speeches are usually performed by someone who has an important role, such as a country leader, company leader, or someone who can inspire his listeners. One of the speeches do it by Anies Baswedan as the Governor of Jakarta in 2019 on the DKI Jakarta provincial government youtube channel for the City of Christchurch, New Zealand.

According to Asmarita \& Haryudin (2019) Deixis is always found in the daily communication or in text, for example in short stories or speech. According to Levinson (1983) in Viahapsari \& Parmawati (2020) deixis is a word which its reference always moves or changes depending on the contex to indicate person, place, time, social distinction, and role in discourse. Deixis 
is used for utterances in speech to indicate the condition of persona, space and time. Based on the statement above, Anies Baswedan uses several types of deixis in his speech, which is one of the important ideas in pragmatics, to show something. As a speaker, Anies Baswedan uses the Deixes function properly. In harmony with (Levinson, 2004) in (Lugina et al., 2019) state that Deixis is the study of deictic or indexical expressions in language, like you, now, today. It can be regarded as a special kind of grammatical property instantiated in the familiar categories of person, tense, place and so on. In this research, five types of deixis is an important point that will be analyzed by researcher. According to Levinson (2004) and Vershueren (2004) in (Purba, 2015), stated that the deixis has five categories; there are person deixis, Place deixis, Time deixis, Discourse deixis, and Social deixis.

\section{Person Deixis}

According to Levinson (1983), Person deixis concerns the encoding of the role of participants in the speech event in which the utterance in question is delivered: the category first person is the speaker's grammaticalization reference for himself, second person the encoding of the speaker's reference to one or more addressees, and third person the encoding of reference to persons and entities which is not the speakers or recipient of the intended speech.

\section{Place Deixis}

According to Levinson (1983), Place deixis concerns the encoding of spatial locations relative to the location of the participants in the speech event. Probably most languages grammaticalize at least a distinction between close to speaker (or proximal) and non-proximal, sometimes close to addressee (or distal), but we will see about many that make a more complicated difference. Such distinctions are commonly encoded in demonstratives (example in English like this vs. that) and in deictic adverbs of place (example in English like here vs. there).

\section{Time Deixis}

According to Levinson (1983) Time deixis concerns the encoding of temporal points and spans relative to the time at which an utterance was spoken (or a written message inscribed). Time deixis is commonly grammaticalized in deictic adverbs of time (example in English like now and then, yesterday and this year). For example: i'll be back in an hour.

\section{Discourse Deixis}

According to Levinson (1983), Discourse deixis relates to coding references to parts of the ongoing discourse where utterances (which include text that refers to expressions) are located. Example of discourse deixis are the use of that and this as follows :

Puff puff puff: that is what it sound like

This is what phoneticians called creaky voice

\section{Social Deixis}

According to Levinson (1983), Social deixis involves coding social differences relative to the participant's role, especially aspects of social relations that occur between speaker and receiver or speaker and some references.

\section{METHOD}

This research was carried out using qualitative descriptive method. According to Anugrah (2018), The type of this qualitative research was content analysis which applied to written 
or visual material. According to Apsari (2017) in Liawati et al., (2020) states qualitative research is syntheticor holistic, heuristic, with little or no control and manipulation of the research content. Therefore, This research was conducted by presenting the results of data analysis from data that has been collected and analyzed in advance. The researcher analyzes the language by watching the video but is not involved in the speech, so the writer uses the nonparticipant observation method, uses audio-visual data uploaded from YouTube, the writer copies the speech into written text, analyzes the deixis used, and determines the type of deixis. The analysis was carried out from the deixis used in Anies Baswedan speech for the City of Christchurch, New Zealand.

\section{RESULTS AND DISCUSSION}

\section{Results}

After analyzing speeches made by Anies Baswedan as Governor of Jakarta in 2019 on the DKI Jakarta provincial government youtube channel for the City of Christchurch, New Zealand. Researchers found that there were several types of deixis used in the speech.The types of deixis used by Anies baswedan in his speech for the City of Christchurch, New Zealand, can be seen in table 1.

Table 1.

Typea of Deixis

\begin{tabular}{ccc}
\hline No. & Types of Deixis & Data \\
\hline 1 & Person Deixis & 6 \\
2 & Place Deixis & 9 \\
3 & Time Deixis & 2 \\
4 & Discourse Deixis & 2 \\
5 & Social Deixis & 6 \\
\hline Total & & 25 \\
\hline
\end{tabular}

\section{Discussion}

Based on the results of research by researchers, in a speech conducted by Anies baswedan using person deixis, place deixis, Time deixis, discourse deixis, and social deixis. So all types of deixis are used by Anies Baswedan in his speech's. When giving a speech, Anies Baswedan uses a good type of deixis and can be adjusted to the events being discussed. In addition, the choice of words and sentences used in his speech is also good because it can be easily understood by people who listen. Researcher analyzed that place deixis was the type of deixis most used in Anies baswedan's speech. The following explanation of the types of deixis used by Anies Baswedan in his speech:

\section{Person Deixis}

According to Asmarita \& Haryudin (2019) Person deixis are the personal pronouns such as the first, second and thrid used as a means of locating the referents in relation to the events taking place in the discourse. First person (I or we), second person (you), and third person (he, she, or they). In conversation, I and you can refer to another person. It depends on who is speaking and has a role as deictic center. Based on that statement above, Researchers find several examples of sentences containing person deixis in Anies baswedan's speech:

(a) we extend our deepest condolences

(b) who is known for their peacefulness 
in point (a), we and our refers to Anies baswedan who represents herself and people who feel sad over the events that occurred in the city of Christchurch, New Zealand. In point (b), their refers to people who are victims, families of victims, residents of the city of Christchurch, and citizens of New Zealand.

2. Place Deixes

According to (Fromkin, 2003) in (Anugrah, 2018) said that, the expression of place deixis require contextual information of the place of the utterance such as here, there, this, place, that, place, this city, etc. Based on that statement above, Researchers find several examples of sentences containing place deixis in Anies baswedan's speech:

(a) Jakarta stands in solidarity with Christchurch.

(b) all victims will be as syuhada, will be granted Jannah

in point (a), Jakarta refers to Jakarta and Indonesian residents who offered condolences, and gave support to the victims' families. Christchurch refers to where the place of terrorism took place and resulting in many casualties. in point (b), Jannah refers to special place from god given to good people when they have died in the Muslim faith.

3. Time Deixes

According to (Ardeatika \& Setiawan, 2019) Time deixis refers to an event of the utterance, which takes place anytime relative to the speaker said. The Example of time deixis, such as yesterday, tomorrow, now. The function of temporal deixis is to show time. Based on that statement above, researchers find several examples of sentences containing time deixis in Anies baswedan's speech:

(a) harrowing news from christchurch came out earlier this afternoon.

(b) in an unthinkable act of terror, in a shooting during jummah prayer.

in point (a), this afternoon refers to the time when people in Indonesia (especially western Indonesia) received news about acts of terrorism in the city of Christchurch. in point (b), during jummah prayer refers to the time when terrorist acts took place in the city of Christchurch, New Zealand.

4. Discourse Deixis

According to (Wiguna et al., 2018) Discourse deixis related to the words or phrases that serve to reveal any part of the sentence in the discourse/speech. Based on that statement above, Researchers find several examples of sentences containing discourse deixis in Anies baswedan's speech:

(a) in a shooting during jummah prayer. in this indeed, shocking and we all feel very saddened.

(b) we believe the government of new zealand will take this matter extremely serious in point (a) and (b), This refers to the problem that occurred about acts of terrorism that took many victims that occurred in the city of Christchurch, New Zealand.

5. Social Deixis

According to (Anugrah, 2018) Social deixis does not refer to time, place, or person, but refers to the rank of society and position between speaking and accepting a society of wisdom. Based on that statement above, Researchers find several examples of sentences containing social deixis in Anies baswedan's speech:

(a) we extend our deepest condolences to the Families of those whose lives had been taken away.

(b) and also to the muslim Community in new Zealand. 
in point (a), Families refers to people who have blood relations or relatives with people who are victims in acts of terrorism that occurred in the city of Christchurch. In point (b), Community refers to a group of people who live in the same place or share certain characteristics (in this context people who are Muslim in the city of Christchurch, New Zealand).

\section{CONCLUSION}

The conclusion is, in his speech Anies baswedan uses all types of deixis, namely person deixis, place deixis, time deixis, discourse deixis, and social deixis. Anies baswedan speech, about condolence to the victims of the terrorist act that took place in the city of Christchurch, new zealand which lasted approximately 1:06 minutes, the amount of data obtained, among others person deixis ( 6 data), place deixis ( 9 data), time deixis ( 2 data), discourse deixis ( 2 data), and social deixis (6 data). In his speech, Anies Baswedan used several types of deixis which were good because they adjusted to the events that were happening at that time. One example of using person deixis is the word "we", because of his position as the governor of Jakarta who represents people to offer their condolences to victims of terrorism in the city of Christchurch, new zealand.

\section{ACKNOWLEDGMENTS}

First of all the researcher thanked Allah SWT, for giving health, strength, and many blessings that could not be explained in words. The researcher also thanked to friends, family, staff of lecturers, who had given me support and prayers to finish this article. Thank you also to Mr. Acep who helped many things in the process of completing this article. Thank you for the patience, sincerity, guidance, correction, and motivation that is always given to me to continue to be spirited in completing this article. Hope Mr. Acep is always given health, protection and many blessings from Allah SWT

Researchers hope this article can be useful for educators as teaching material in the learning process inside or outside the classroom, useful for students to be able to add to existing insights for the better, and useful for other researchers as reference material in making articles or research.

\section{REFERENCES}

Anugrah, S. V. (2018). Analysis Of Deixis In The Story Selected From Christian Bible, Genesis. PROJECT (Professional Journal of English Education), 1(5), 664-670.

Ardeatika, M., \& Setiawan, M. N. (2019). Deixis in the Spiderwick Chronicles Movie Script. PROJECT (Professional Journal of English Education), 2(2), 210. https://doi.org/10.22460/project.v2i2.p210-213

Asmarita, A., \& Haryudin, A. (2019). an Analysis Deixis in Ridwan Kamil'S Speech At the Asia Africa Conference (Kaa). PROJECT (Professional Journal of English Education), 2(5), 622. https://doi.org/10.22460/project.v2i5.p622-627

Levinson, S. C. (1983). Pragmatics - part 1 of 2. Press Syndicate of the University of Cambridge.

Liawati, A., Rizkiani, S., \& Jamaludin, A. (2020). Deixis in the clever servant story. PROJECT (Professional Journal of English Education), 3(1), 2014-2018.

Lugina, G., R, E. N., \& Suprijadi, D. (2019). Deixis in the Legend of Lake Toba Story. PROJECT (Professional Journal of English Education), 2(5), 640. 
https://doi.org/10.22460/project.v2i5.p640-644

Purba, R. (2015). Deixis in inauguration speech of President Susilo Bambang Yudhoyono. Jurnal Mantik Penusa, 17(1), 75-85.

Viahapsari, E., \& Parmawati, A. (2020). Analysis The Type Of Deixis In The Main Character On The Movie I Leave My Heart In Lebanon. PROJECT (Professional Journal of English Education), 3(3), 388-394.

Wiguna, A., Anggraeni, H., Nuramalia, R., \& Irma, S. S. (2018). Deixis in Maleficent Movie Script. PROJECT (Professional Journal of English Education), 1(2), 133-138. https://journal.ikipsiliwangi.ac.id/index.php/project/article/view/466. 